\title{
ANALISIS PENERAPAN DAN PERLAKUAN AKUNTANSI MURABAHAH UNTUK PEMBIAYAAN KONSUMTIF
}

\author{
Ika Rahmadani, SE, M.Si, Ak \\ ikaramadhani@utu.ac.id
}

\begin{abstract}
This study aims to know the implementation of murabahah financing in PT. Bank Muamalat Indonesia branch office Banda Aceh, such as the rule of murabahah financing, the procedure of murabahah financing, and accounting of Murabahah financing and the conformity of its implementation to Statement of Financial Accounting Standards (PSAK) No. 102. The study conducted by using a descriptive method. Descriptive method is to conclude, interpret and clarify the data in accordance with the actual events. The type of data used are primary data and secondary data that obtained from interviews with financing staff in PT Bank Muamalat Indonesia Branch Office Banda Aceh. The authors obtained the results of research with a conclusion that the practices in PT Bank Muamalat Indonesia Branch Office Banda Aceh is compliance with the Statement of Financial Accounting Standards (PSAK) No. 102.
\end{abstract}

Kata kunci: pembiayaan murabahah, akuntansi pembiayaan murabahah, pembiayaan konsumen, PSAK 102

\section{PENDAHULUAN}

Seiring dengan perkembangan lembaga-lembaga keuangan syariah, maka berkembang pula wacana mengenai akuntansi syariah. Hal ini terkait karena keberadaan suatu lembaga atau perusahaan, tidak akan terlepas dari proses pencatatan akuntansi. Setiap lembaga atau perusahaan berkewajiban melakukan pencatatan atas aktivitas-aktivitas akuntansi yang terjadi dalam perusahaan yang selanjutnya disajikan dalam bentuk laporan keuangan.Wacana mengenai akuntansi syariah muncul karena kebutuhan akan bingkai transaksi keuangan yang kokoh dan mapan, sehingga dapat mengawal segala transaksi-transaksi keuangan sesuai dengan prinsip syariah. Akuntansi syariah juga berfokus pada pelaporan yang jujur mengenai posisi keuangan entitas dan hasil-hasil operasi, sehingga dapat mengungkapkan transaksi halal dan haram. Aturan-aturan yang diterapkan pun dapat melindungi hak dan kewajiban perorangan dan menjamin pengungkapan yang memadai.

Falsafah dasar perbankan syariah mengacu kepada ajaran agama Islam yang bersumber pada Al-quran, al-hadis, dan al-ijtihad. Fungsi bank syariah antara lain menghimpun dan menyalurkan dana kepada masyarakat, dimana penyaluran dana ini terdiri dari berbagai bentuk produk bank syariah di antaranya adalah produk pendanaan, produk pembiayaan, produk jasa perbankan, dan produk sosial.

Dalam melaksanakan kegiatan penghimpunan dana, bank syariah menerima simpanan dari masyarakat. Sedangkan dalam kegiatan penyaluran dana, bank syariah memberikan jasa dalam bentuk pembiayaan dan investasi. Pembiayaan di bank syariah merupakan salah satu tulang punggung kegiatan 
perbankan. Terdapat beberapa jenis pembiayaan yang ditawarkan oleh bank syariah, diantaranya pembiayaan murabahah. Pembiayaan murabahah sendiri merupakan transaksi yang banyak dipilih sebagai skema penyaluran dana dari bank syariah. Murabahah adalah pembiayaan dengan prinsip jual beli barang pada harga asal dengan tambahan keuntungan yang disepakati, dengan pihak bank selaku penjual dan nasabah sebagai pembeli. Pembayaran dapat dilakukan secara angsuran ataupun ditangguhkan sesuai dengan kesepakatan bersama.

Pembiayaan murabahah membutuhkan kerangka akuntansi yang menyeluruh yang dapat menghasilkan pengukuran akuntansi yang tepat dan sesuai sehingga dapat mengkomunikasikan informasi akuntansi secara tepat waktu dengan kualitas yang dapat diandalkan serta mengurangi adanya perbedaan perlakuan akuntansi antara bank syariah yang satu dengan yang lain. Perbedaan perlakuan tersebut akan mengakibatkan dampak terhadap hal keadilan dalam menentukan laba bagi pemegang saham dan depositor. Pada saat akad penyaluran pembiayaan murabahah harus terdapat kepastian mengenai biaya perolehan dan tambahan keuntungan yang disepakati .

Pembiayaan murabahah merupakan konsep yang cocok untuk digunakan dalam pembiayaan modal kerja, investasi dan konsumtif. Tetapi, pembiayaan murabahah sendiri menjadi skema pembiayaan yang banyak diminati nasabah untuk memenuhi kebutuhan konsumtif mereka. Pada Bank Muamalat cabang Banda Aceh, nasabah pembiayaan konsumtif dari akhir Desember 2009 hingga akhir September 2010 berturut-turut adalah $65 \%$ dan $68 \%$ dari total nasabah pembiayaan. Pembiayaan konsumtif sendiri adalah jenis pembiayaan yang diberikan untuk tujuan diluar usaha dan umumnya bersifat perorangan. Pembiayaan konsumtif digunakan untuk memenuhi kebutuhan konsumsi dan akan habis dipakai untuk memenuhi kebutuhan tersebut, seperti pembiayaan hunian syariah (pembelian alatalat bangunan dan tanah), pembelian mobil, pembelian sepeda motor dan pembelian alat-alat rumah tangga.

Lembaga keuangan bank syariah menggunakan PSAK nomor 59 yang telah menjadi standar baku bagi operasional perbankan syariah di Indonesia, revisi PSAK 59 yaitu PSAK 101-106 tahun 2007 yang mengatur lebih rinci mengenai akad-akad syariah ( PSAK 102 tentang akad murabahah) dan PAPSI 2003 sebagai standar pengukurannya. Penerapan standar-standar tersebut dapat menjaga konsistensi, baik yang bersifat internal maupun eksternal bank, maupun untuk menjamin kesesuaiannya dengan syariat Islam.

Pemahaman masyarakat tentang produk-produk perbankan syariah masih tergolong minim. Dapat dilihat dari total aset perbankan syariah hingga Oktober 2010 hanya sebesar 3,1\% dari keseluruhan total aset perbankan nasional. Oleh karena itu, perkembangan informasi dan literatur-literatur mengenai perbankan syariah secara khusus dan ekonomi islam secara umum dapat memperkaya wawasan masyarakat, dan meningkatkan kesadaran masyarakat.

Berdasarkan uraian tersebut, maka penulis tertarik untuk melakukan penelitian dan membuat skripsi dengan judul : Analisis Penerapan dan Perlakuan Akuntansi Murabahah untuk Pembiayaan Konsumtif Studi Kasus pada PT. Bank Muamalat Indonesia Cabang Banda Aceh. 


\section{TINJAUAN PUSTAKA \\ Perbankan Syariah}

Bank yang menjalankan kegiatan operasionalnya dengan prinsip bagi hasil, berfungsi sebagai lembaga intermediasi yaitu, menghimpun dana dari masyarakat dan menyalurkan dana kepada masyarakat yang membutuhkan dana tersebut.

Pengertian bank syariah dalam pasal 1 butir 7 UU No. 21 tahun 2008 tentang perbankan syariah disebutkan: "Bank Syariah adalah Bank yang menjalankan kegiatan usahanya berdasarkan Prinsip Syariah dan menurut jenisnya terdiri atas Bank Umum Syariah dan Bank Pembiayaan Rakyat Syariah.”

\section{Tujuan dan Keistimewaan Bank Syariah}

a. Tujuan Bank Syariah Bank-bank syariah dibentuk dengan tujuan sebagai berikut:

i. Mengarahkan kegiatan ekonomi umat untuk bermuamalah secara Islam khususnya muamalah yang berhubungan dengan perbankan, agar terhindar dari praktek-praktek riba atau jenis usaha/perdagangan lain yang mengandung unsur haram dimana jenis-jenis usaha tersebut selain dilarang dalam Islam, juga menimbulkan dampak negatif terhadap kehidupan ekonomi umat.

ii. Untuk menciptakan suatu keadilan di bidang ekonomi, dengan jalan meratakan pendapatan melalui kegiatan investasi agar tidak terjadi kesenjangan yang amat besar, antara pemilik modal dengan pihak yang membutuhkan modal.

iii. Untuk meningkatkan kualitas hidup umat, dengan jalan membuka peluang usaha yang lebih besar terutama kepada kelompok miskin yang diarahkan kepada kegiatan usaha yang produktif, menuju terciptanya kemandirian berusaha.

iv. Untuk membantu menanggulangi (mengentaskan garis kemiskinan), yang pada umumnya merupakan program utama dari negara-negara yang sedang berkembang. Upaya bank syariah dalam mengentaskan kemiskinan ini berupa pembinaan nasabah yang lebih menonjol sifat kebersamaan dari siklus usaha yang lengkap seperti program pembinaan pengusaha produsen, pembinaan pedagang perantara, program pembinaan konsumen, program pengembangan modal kerja dan program pengembangan usaha bersama.

v. Untuk menjaga kestabilan ekonomi dan moneter pemerintah. Dengan aktivitas-aktivitas bank syariah yang diharapkan mampu menghindarkan inflasi akibat penerapan sistem bunga, menghindarkan persaingan yang tidak sehat antara lembaga keuangan, khususnya bank dan menanggulangi kemandirian lembaga keuangan, khususnya bank dari pengaruh gejolak moneter baik dari dalam maupun luar negeri.

vi. Untuk menyelamatkan ketergantungan umat islam terhadap bank non-islam yang menyebabkan umat islam berada dibawah kekuasaan bank, sehingga umat Islam tidak bisa melaksanakan 
ajaran agamanya secara penuh, terutama di bidang kegiatan bisnis dan perekonomiannya.

b. Keistimewaan Bank Syariah

Bank Syariah memiliki keistimewaan-keistimewaan yang juga merupakan perbedaan jika dibandingkan dengan bank konvensional. Sumitro (2004:22) memberikan pemahamannya mengenai keistimewaan bank syariah :

i. Adanya kesamaan ikatan emosional yang kuat antara pemegang saham, pengelola bank dan nasabahnya.

ii. Diterapkannya sistem bagi hasil sebagai pengganti bunga, akan menimbulkan akibat-akibat yang positif.

iii. Di dalam Bank Syariah, tersedia fasilitas kredit kebaikan (al-Qardhul Hasan) yang diberikan secara cuma-cuma.

iv. Keistimewaan yang paling menonjol dari bank syariah adalah melekat pada konsep (built in concept).

v. Keistimewaan lain bank syariah adalah dengan penerapan sistem bagi hasil berarti tidak membebani biaya diluar kemampuan nasabah dan akan menjamin adanya keterbukaan.

vi. Adanya kenyataan bahwa dalam kehidupan ekonomi masyarakat modern cenderung akan menimbulkan pengeksploitasian kelompok kuat ekonomi dan politik) dan kelompok lemah. Kenyataan ini menimbulkan reaksi balik dari kelompok lemah yang mayoritas untuk berkreasi bagi munculnya kehidupan ekonomi yang berkeadilan.

c. Akuntansi Perbankan Syariah

Akuntansi merupakan kegiatan mencatat, menggolongkan, mengiktisarkan sehingga dihasilkan informasi keuangan dalam bentuk laporan keuangan yang dapat digunakan untuk pengambilan keputusan. Akuntansi syariah merupakan serangkaian proses akuntansi atas transaksi-transaksi yang sesuai dengan aturanaturan yang telah ditetapkan Allah SWT.

Akuntansi syariah sangat diperlukan untuk mendukung kegiatan yang dilakukan sesuai dengan syariah Islam. Akuntansi dalam Islam sendiri, antara lain berhubungan dengan pengakuan, pengukuran dan pencatatan transaksi dan pengungkapan hak-hak dan kewajiban-kewajibannya secara adil.

Akuntansi keuangan sangat erat kaitannya dengan penyediaan informasi yang berguna untuk membantu para penmakai di dalam pengambilan keputusan. Menurut Harahap (2004 : 21) tujuan akuntansi bank syariah, yaitu :

1. Menentukan hak dan kewajiban pihak terkait, termasuk hak dan kewajiban yang berasal dari transaksi yang belum selesai dan atau kegiatan ekonomi lain, sesuai dengan prinsip syariah yang berlandaskan pada konsep kejujuran, keadilan, kebijakan, dan kepatuhan terhadap nilai-nilai bisnis islami

2. Menyediakan informasi keuangan yang bermanfaat bagi para pemakai laporan dalam pengambilan keputusan, dan

3. Meningkatkan kepatuhan terhadap prinsip syariah dalam semua transaksi dan kegiatan usaha.

Untuk mencapai tujuan-tujuan tersebut, laporan keuangan bank syariah haruslah disesuaikan dengan PSAK No. 59, 101-106 dan PAPSI 2003. PSAK 
nomor 59 tentang Akuntansi Perbankan Syariah berisi tentang ketentuanketentuan pokok, PSAK 101-106 revisi dari PSAK No. 59 tentang aturan akadakadnya dan untuk melengkapinya digunakan juga Pedoman Akuntansi Perbankan Syariah Indonesia (PAPSI) 2003 sebagai standar pengukurannya.

d. Pembiayaan di Bank Syariah

Dalam UU No. 21 Tahun 2008 tentang Perbankan Syariah disebutkan pada pasal 1 angka 25:

Pembiayaan adalah penyediaan dana atau tagihan yang dipersamakan dengan itu berupa:

a. transaksi bagi hasil dalam bentuk mudharabah dan musyarakah;

b. transaksi sewa-menyewa dalam bentuk ijarah atau sewa beli dalam bentuk ijarah muntahiya bittamlik;

c. transaksi jual beli dalam bentuk piutang murabahah, salam, dan istishna';

d. transaksi pinjam meminjam dalam bentuk piutang qardh; dan

e. transaksi sewa-menyewa jasa dalam bentuk ijarah untuk transaksi multijasa berdasarkan persetujuan atau kesepakatan antara Bank Syariah dan/atau UUS dan pihak lain yang mewajibkan pihak yang dibiayai dan/atau diberi fasilitas dana untuk mengembalikan dana tersebut setelah jangka waktu tertentu dengan imbalan ujrah, tanpa imbalan, atau bagi hasil.

Dari sekian banyak produk pembiayaan bank syariah, tiga produk utama yang mendominasi portofolio pembiayaan bank syariah adalah pembiayaan modal kerja, pembiayaan investasi dan pembiayaan aneka barang, perumahan dan property.

Menurut sifat penggunaannya, pembiayaan dapat dibagi menjadi dua hal berikut

1. Pembiayaan Produktif,

Pembiayaan produktif yaitu pembiayaan yang ditujukan untuk memenuhi kebutuhan produksi dalam arti luas, yaitu untuk peningkatan usaha baik usaha produksi, perdagangan maupun investasi. Menurut keperluan pembiayaan produktif dapat dibagi menjadi dua hal, yaitu:

a. Pembiayaan modal kerja

Pembiayaan modal kerja, yaitu pembiayaan untuk memenuhi kebutuhan peningkatan produksi, baik secara kuantitatif maupun kualitatif dan untuk keperluan perdagangan atau peningkatan utility of place dari suatubarang.Unsur-unsur modal kerja terdiri atas komponen-komponen alat likuid, piutang dagang (receivable), dan persediaan (inventory) yang umumnya terdiri atas persediaan bahan baku (raw material), persediaan barang dalam proses (work in process), dan persediaan barang jadi (finished goods). Oleh karena itu, pembiayaan modal kerja merupakan salah satu atau kombinasi dari pembiayaan likuiditas (cash financing), pembiayaan piutang (receivable financing), dan pembiayaan persediaan (inventory financing).

b. Pembiayaan investasi Pembiayaan investasi diberikan kepada para nasabah untuk keperluan investasi, yaitu keperluan penambahan modal 
guna mengadakan rehabilitasi, perluasan usaha, ataupun pendirian proyek baru.

Pada umumnya, pembiayaan investasi diberikan dalam jumlah besar dan pengendapannya cukup lama. Oleh karena itu, perlu disusun proyeksi arus kas (project cash flow) yang mencakup semua komponen biaya dan pendapatan sehingga akan dapat diketahui berapa dana yang tersedia setelah semua kewajiban terpenuhi. Selain itu, barulah disusun jadwal amortisasi yang merupakan angsuran pembiayaan.

Melihat luasnya aspek yang harus dikelola dan dipantau maka untuk pembiayaan investasi bank syariah menggunakan skema musyarakah mutanaqishah. Dalam hal ini, bank memberikan pembiayaan dengan prinsip penyertaan, dan secara bertahap bank melepaskan penyertaan dan pemilik perusahaan akan mengambilalih kembali, baik dengan menggunakan surplus cash flow yang tercipta maupun dengan menambah modal, baik yang berasal dari setoran pemegang saham yang ada maupun dengan mengundang pemegang saham baru. Skema lain yang dapat digunakan oleh bank syariah adalah al-ijarah al muntahiabit-tamlik, yaitu menyewakan barang modal dengan opsi diakhiri dengan pemilikan. Sumber perusahaan untuk pembayaran sewa ini adalah amortisasi atas barang modal yang bersangkutan, surplus, dan sumber-sumber lain yang dapat diperoleh perusahaan.

2) Pembiayaan Konsumtif

Pembiayaan konsumtif diperlukan oleh pengguna dana untuk memenuhi kebutuhan konsumsi dan akan habis dipakai untuk memenuhi kebutuhan tersebut. Kebutuhan konsumsi dapat dibedakan atas kebutuhan primer dan sekunder. Kebutuhan primer adalah kebutuhan pokok, baik berupa barang, seperti makanan dan minuman, pakaian/perhiasan, bangunan rumah, kendaraan, dan sebagainya, maupun berupa jasa, seperti pendidikan, pelayanan kesehatan, pariwisata, hiburan dan sebagainya.

Menurut Antonio (2001 : 168) Bank syariah dapat menyediakan pembiayaan komersil untuk pemenuhan kebutuhan barang konsumsi dengan menggunakan skema berikut ini,

1. Al-bai' bi tsaman ajil (salah satu bentuk murabahah) atau jual beli dengan angsuran.

2. Al-ijarah al muntahia bit-tamlik atau sewa beli.

3. Al-musyarakah mutanaqhishah dan decreasing participation, dimana secara bertahap bank menurunkan jumlah partisipasinya.

4. Ar-rahn untuk memenuhi kebutuhan jasa.

\section{Sistem Pembiayaan Murabahah}

Menurut PSAK No. 59 tentang akuntansi perbankan syariah, murabahah adalah akad jual beli barang dengan menyatakan harga perolehan dan keuntungan (margin) yang di sepakati oleh penjual dan pembeli. Di dalam PSAK 102 paragraf 5 murabahah adalah akad jual beli barang dengan harga jual sebesar biaya perolehan ditambah keuntungan yang disepakati dan penjual harus 
mengungkapkan biaya perolehan barang tersebut kepada pembeli. Definisi ini menunjukkan bahwa transaksi murabahah tidak harus dalam bentuk pembayaran tangguh atau kredit, melainkan dapat juga dalam bentuk tunai setelah menerima barang, ditangguhkan dengan mencicil setelah menerima barang, ataupun ditangguhkan dengan membayar sekaligus dikemudian hari (PSAK 102 paragraf 8). Sedangkan dalam fatwa Dewan Syariah Nasional yang dimaksud dengan murabahah adalah menjual suatu barang dengan menegaskan harga belinya kepada pembeli dan pembeli membayarnya dengan harga yang lebih sebagai laba. 2000: 93):

Murabahah sesuai jenisnya dapat dikategorikan dalam dua jenis (Harahap

1). Murabahah tanpa pesanan artinya ada yang beli atau tidak, bank syariah menyediakan barang dan

2). Murabahah berdasarkan pesanan artinya bank syariah baru akan melalukan transaksi jual beli apabila ada yang pesan. Murabahah berdasarkan pesanan dapat dikategorikan dalam: sifatnya mengikat artinya murabahah berdasarkan pesanan tersebut mengikat untuk dibeli oleh nasabah sebagai pemesan, dan sifatnya tidak mengikat artinya walaupun nasabah telah melakukan pemesanan barang, namun nasabah tidak terikat untuk membeli barang tersebut.

d. Perlakuan Akuntansi Murabahah

Standar akuntansi tentang jual beli murabahah mengacu pada PSAK 102 tentang Akuntansi Murabahah yang mulai berlaku efektif sejak 1 Januari 2008. PSAK ini menggantikan PSAK 59 yang berhubungan dengan pengakuan, pengukuran, penyajian, dan pengungkapan murabahah. PSAK 102 dapat diterapkan untuk lembaga keuangan syariah seperti bank, asuransi, lembaga pembiayaan, dana pensiun, koperasi, dan lainnya yang menjalankan transaksi murabahah. Disamping itu, PSAK 102 juga diterapkan oleh pihak-pihak yang melakukan transaksi murabahah dengan lembaga keuangan tersebut. 


\section{Kerangka Konseptual}

Untuk menyelesaikan masalah yang tertuang dalam skripsi ini, penulis akan menguraikan alur berfikir penulis dalam kerangka konseptual sebagai berikut:

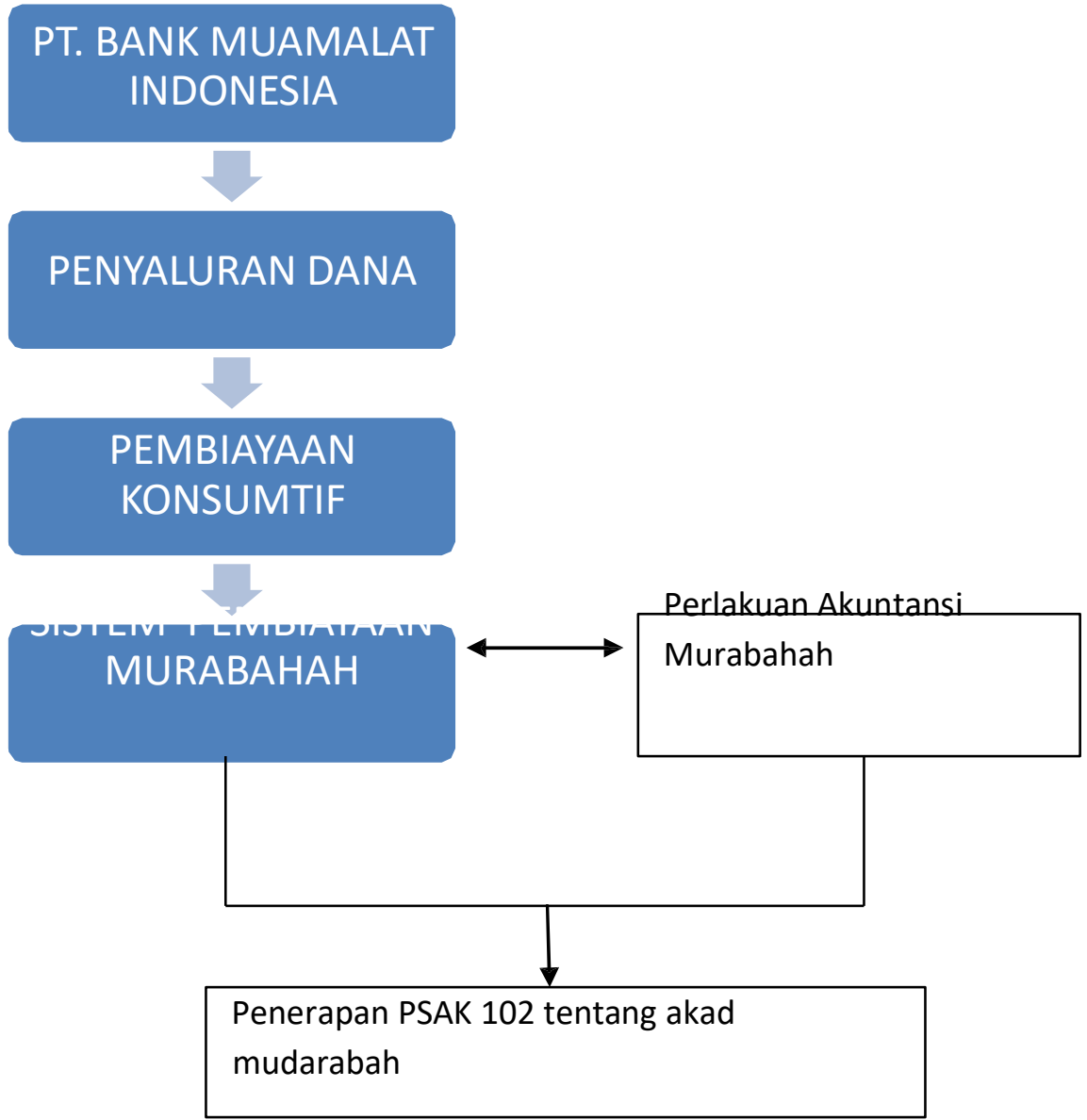

Gambar 1.1 Kerangka Konseptual Sumber : Penulis, 2010

\section{METODOLOGI PENELITIAN}

Penelitian yang dilakukan berupa studi kasus yang bersifat deskriptif yaitu dengan cara menguraikan tentang keadaan dan sifat-sifat yang sebenarnya dari objek penelitian. Jenis data yang penulis gunakan dalam penulisan skripsi ini adalah:

1. Data primer

Data primer adalah data yang diperoleh langsung dari perusahaan dan membutuhkan pengolahan lebih lanjut. Contoh : hasil wawancara

2. Data sekunder

Data sekunder adalah data yang di peroleh dalam bentuk yang sudah jadi, seperti laporan keuangan, struktur organisasi, dan lain-lain.

\section{Teknik pengumpulan data}

Teknik pengumpulan data yang digunakan dalam penulisan skripsi ini adalah: 
1. Teknik Observasi, yaitu mengadakan pengamatan langsung pada dokumen dan aktivitas yang berhubungan dengan perlakuan akuntansi perbankan syariah.

2. Teknik Wawancara, yaitu dengan melakukan wawancara langsung kepada beberapa karyawan untuk mendapatkan informasi tambahan mengenai Bank Muamalat Indonesia cabang Medan.

3. Teknik Dokumentasi, yaitu dengan meneliti bahan-bahan tulisan perusahaan dan dokumen perusahaan yang berhubungan dengan penelitian.

\section{Metode analisa data}

Metode analisa data yang digunakan dalam penelitian ini adalah :

1. Metode analisa deskriptif, merupakan suatu metode atau prosedur pemecahan masalah yang diselidiki, dengan menggambarkan atau melukiskan keadaaan objek penelitian pada saat sekarang, berdasarkan fakta-fakta yang tampak atau sebagaimana adanya.

2. Metode komparatif, merupakan metode analisis yang dilakukan dengan membandingkan teori-teori dengan praktek dalam perusahaan, kemudian mengambil kesimpulan yang sebenarnya dari masalah yang di teliti.

\section{ANALISIS HASIL PENELITIAN}

\section{Sejarah PT. Bank Muamalat Indonesia}

PT. Bank Muamalat Indonesia, Tbk didirikan di Republik Indonesia pada tanggal 24 Rabiuts Tsani $1412 \mathrm{H}$ atau 1 November $1991 \mathrm{M}$ yang di prakarsai oleh beberapa tokoh Majelis Ulama Indonesia (MUI) dan Ikatan Cendekiawan Muslim se-Indonesia (ICMI) dengan dukungan Pemerintah Republik Indonesia berdasarkan akta Notaris Yudo Paripurno, SH No. 1 . Sesuai dengan pasal 3 anggaran dasar Bank Muamalat Indonesia yang terakhir, ruang lingkup kegiatan bank adalah menyelenggarakan usaha perbankan dengan prinsip syariah. Berdasarkan Surat Keputusan Menteri Keuangan Republik Indonesia No. 430/KMK.013/1992 tanggal 24 April 1992, Bank telah memperoleh izin beroperasi sebagai Bank Umum . Bank memulai aktivitas operasinya pada 27 Syawal $1412 \mathrm{H}$ atau bertepatan dengan tanggal 1 Mei 1992 dengan dukungan dari tokoh-tokoh dan pemimpin muslim terkemuka serta beberapa pengusaha muslim. Pendiriannya juga mendapat dukungan masyarakat sehingga jumlah modal awal menjadi total sebesar Rp. 106 Miliar.

Kantor Pusat Bank Muamalat berlokasi di Gedung Arthaloka Jalan Jenderal Sudirman No. 2 Jakarta 10220. Bank Muamalat saat ini telah mempunyai 73 Kantor Cabang, 50 Kantor Cabang Pembantu, 132 Kantor Kas dan 4000 kantor pos online/SOPP Pos di seluruh Indonesia, 32000 ATM dan 95.000 merchant debet.

BMI saat ini juga merupakan satu-satunya bank syariah yang telah membuka cabang luar negeri, yaitu di Kuala Lumpur, Malaysia. Untuk meningkatkan aksesibilitas nasabah di Malaysia, kerjasama dijalankan dengan jaringan Malaysia Electronic Payment System (MEPS) sehingga layanan BMI dapat diakses di lebih dari 2000 ATM di Malaysia. Sebagai Bank Pertama Murni Syariah, bank muamalat berkomitmen untuk menghadirkan layanan perbankan 
yang tidak hanya comply terhadap syariah, namun juga kompetitif dan aksesibel bagi masyarakat hingga pelosok nusantara. Komitmen tersebut diapresiasi oleh pemerintah, media massa, lembaga nasional dan internasional serta masyarakat luas melalui lebih dari 70 award bergengsi yang diterima oleh BMI dalam 5 tahun Terakhir. Penghargaan yang diterima antara lain sebagai Best Islamic Bank in Indonesia 2009 oleh Islamic Finance News (Kuala Lumpur), sebagai Best Islamic Financial Institution in Indonesia 2009 oleh Global Finance (New York) serta sebagai The Best Islamic Finance House in Indonesia 2009 oleh Alpha South East Asia (Hong Kong).

\section{Pembiayaan Murabahah Konsumtif}

Pembiayaan murabahah merupakan jenis skema pembiayaan yang paling banyak diminati dan merupakan skema pembiayaan dengan jumlah penyaluran dana paling besar di Bank Muamalat cabang Medan. Dilihat dari data yang penulis peroleh dari Bank Muamalat cabang Medan (data per 31 Desember 2009 dan 30 September 2010), yang telah penulis uraikan ke dalam bentuk diagram didalam sub bab sebelumnya. Skema jual beli ini menjadi skema pembiayaan yang memiliki peran penting dalam penyaluran dana Bank Muamalat cabang Medan karena memiliki nominal terbesar dibandingkan skema pembiayaan lainnya. Berturutturut data dari 31 Desember 2009 dan 30 September 2010 nominal pembiayaan murabahah Rp. 84.273.776.673,89 dan Rp.

127.683.993.881,51 yaitu $45 \%$ dan 57\% dari keseluruhan pembiayaan Bank Muamalat. Sejalan dengan hal itu jumlah nasabah pembiayaan murabahah berturut-turut dari 31 Desember 2009 dan 30 September 2010 adalah 1008 dan 718 nasabah yaitu $56 \%$ dan $49 \%$ dari total jumlah nasabah pembiayaan secara keseluruhan.

Sedangkan pembiayaan konsumtif, (seperti pembiayaan hunian syariah dan pembelian mobil) merupakan tujuan pembiayaan yang paling diminati nasabah bank muamalat berturut-turut data dari 31 Desember 2009 dan 30 September 2010 adalah 1163 dan 1019 nasabah yaitu masing-masing $65 \%$ dan 68 $\%$ dari keseluruhan nasabah pembiayaan dengan tujuan konsumtif. Nilai nominal pembiayaan konsumtif berturut-turut dari 31 Desember 2009 dan 30 September 2010 adalah Rp. 76.087.620.880 dan Rp.75.198.788.928 yaitu 40 \% dan 33 \% dari keseluruhan pembiayaan di Bank Muamalat. Tetapi, nilai nominal pembiayaan konsumtif di Bank Muamalat cabang Medan memiliki proporsi yang lebih kecil dibandingkan dengan pembiayaan produktif, berdasarkan data di Bank Muamalat berturut-turut dari 31 Desember 2009 dan 30 September 2010 pembiayaan produktif berjumlah Rp. 111.189.785.400 (pembiayaan investasi sebesar Rp.

55.644.253.013 dan pembiayaan modal kerja sebesar Rp. 56.545.532.392) dan Rp. 147.330.539.300 (pembiayaan investasi sebesar Rp. 92.228.141.766 dan pembiayaan modal kerja sebesar Rp. 55.102.397.559).

Skema murabahah untuk pembiayaan konsumtif merupakan tujuan pembiayaan dengan jumlah nasabah terbanyak dengan jumlah berturut-turut dari 31 Desember 2009 dan 30 September 2010 adalah 894 dan 611 nasabah yaitu sekitar $88 \%$ dan $85 \%$ dari keseluruhan nasabah skema murabahah dengan tujuan pembiayaan konsumtif. Dari segi nominal, pembiayaan murabahah dengan tujuan pembiayaan konsumtif berturut-turut dari 31 Desember 2009 dan 30 September 
2010 hanya berkisar Rp. 29.978.145.188 dan Rp.25.050.229.441 atau secara persentase sebesar $35 \%$ dan 19,6 \% dari jumlah keseluruhan skema pembiayaan murabahah.

Hal ini membuktikan bahwa Bank Muamalat cabang Medan masih beroperasi sejalan dengan tujuan Bank Syariah pada umumnya dengan lebih mengutamakan penyaluran dana untuk tujuan pembiayaan produktif (pembiayaan modal kerja dan pembiayaan investasi) dalam upaya untuk mewujudkan kesejahteraan umat. Dengan tidak menjadikan pembiayaan konsumtif sebagai fokus utama kegiatan penyaluran dana di Bank Muamalat cabang Medan, tetapi tetap merangkul kebutuhan masyarakat akan pembiayaan konsumtif tersebut sesuai dengan proporsinya.

\section{Analisis Prosedur Pembiayaan Murabahah}

Awal proses dalam prosedur pembiayaan adalah pengisian ,formulir permohonan pembiayaan secara manual mengenai data-data calon pemohon pembiayaan. Setelah semua data dan dokumen yang dibutuhkan telah diserahkan oleh nasabah, selanjutnya kelengkapannya akan diperiksa oleh petugas Bank.

Account Manager, yang kemudian akan membubuhkan parafnya pada dokumen-dokumen tersebut sebagai bukti bahwa kebenaran dokumen telah diperiksa sekaligus menanggungjawabi pemeriksaan semua dokumen-dokumen tersebut. Selanjutnya, Kepala Administrasi Kredit Marketing wajib memeriksa kembali kelengkapan dokumen dengan jalan membandingkannya terhadap checklist yang tersedia, serta memberitahukannya kepada Account Manager jika terdapat kekurangan.

Selanjutnya Account Manager akan melakukan analisis 5c terhadap kelayakan permohonan pembiayaan tersebut,

a. Character

dalam tahap ini akan dianalisis Watak/Sifat dari calon nasabah;

b. Capacity

Kemampuan yang dinilai antara lain kemampuan menjalankan usaha sehingga nantinya nasabah mampu melunasi tagihan pembiayaan;

c. Capital

Analisis ini bertujuan untuk mengukur kemampuan usaha calon nasabah untuk mendukung pembiayaan modalnya sendiri. Semakin besar kemampuan modal berarti semakin besar porsi pembiayaan yang didukung oleh modal sendiri. Dalam tahap ini akan dianalisa modal yang dimiliki calon nasabah oleh Account Manager, untuk mengetahui modal yang dimilikinya untuk menutupi apabila terjadi resiko kredit;

d. Condition of Economy

Selanjutnya akan dinilai kondisi perekonomian saat ini secara umum serta kondisi usaha calon nasabah oleh Account Manager;

e. Collateral

Setiap pemberian pembiayaan harus disertai dengan jaminan fisik yang jumlah dan nilainya harus dapat menjamin besarnya pembiayaan yang disetujui. Jaminan pembiayaan harus benar-benar dapat dikuasai serta diyakini kebenaran status pemiliknya. Account Manager juga 
menganalisis jaminan atau agunan yang diberikan nasabah apakah dapat mencukupi sebagai antisipasi apabila nasabah nantinya tidak mampu membayar tagihan pembiayaannya.

Setelah dilakukan analisis kelayakan tersebut, selanjutnya kredit investigator akan melalukan taksasi jaminan secara lebih terperinci. Apabila diperlukan oleh Bank. Kemudian dokumen jaminan dicatat secara terperinci, dan disimpan dengan baik dan prosedur penyimpanannya dilaksanakan sesuai instruksi Operasi yang berlaku. Sebagai catatan silang (cross reference) nomor dari Lembar Majemuk Tanda Terima Barang Jaminan akan dicatat pada Kartu Pinjaman/Pembiayaan. Seorang Pejabat Bank akan membubuhkan parafnya pada Kartu Pinjaman/Pembiayaan sebagai tanda ketentuan tersebut telah dilaksanakan sebagaimana mestinya. Hal ini berguna sebagai kontrol internal juga sebagai tingkat pengamanan terhadap dokumen milik nasabah. Apabila pembiayaan melebihi 250 juta, akan dilakukan analisis resiko oleh Financial Risk Officer.

Setelah permohonan disetujui akan dilanjutkan dengan proses dokumentasi yang dikerjakan oleh Unit Support Pembiayaan Dana, yang kemudian akan dilanjutkan dengan pengisian data melalui sistem komputerisasi.

\section{Analisis Penerapan Akuntansi Murabahah}

Dari hasil penelitian diperoleh hasil bahwa pembiayaan murabahah yang dilakukan oleh PT. Bank Muamalat Indonesia, Tbk telah sesuai dengan PSAK No. 102 tentang Akuntansi Murabahah. Kesesuaian tersebut antara lain:

a. PT. Bank Muamalat Indonesia, Tbk cabang Medan dalam melaksanakan pembiayaan murabahah bertindak sebagai penjual dengan menyatakan harga jual dan keuntungan yang disepakati antara bank dan nasabah.(sesuai dengan PSAK 102 paragraf 22)

b. PT. Bank Muamalat Indonesia, Tbk mengakui diskon pembelian aset murabahah sebagai ; (a) pengurang biaya perolehan aset murabahah, jika terjadi sebelum akad murabahah, (b) kewajiban kepada pembeli, jika terjadi setelah akad murabahah dan sesuai dengan akad yang disepakati menjadi hak pembeli, (c) tambahan keuntungan murabahah, jika terjadi setelah akad murabahah dan sesuai akad menjadi hak penjual, atau (d) pendapatan operasi lain, jika terjadi setelah akad murabahah dan tidak diperjanjikan dalam akad. (sesuai dengan PSAK 102 paragraf 20)

c. PT. Bank Muamalat Indonesia, Tbk mengakui keuntungan murabahah secara proporsional dengan besaran kas yang berhasil ditagih dari piutang murabahah. (sesuai dengan PSAK 102 paragraf 23 (b) (ii))

d. PT. Bank Muamalat Indonesia, Tbk akan mengenakan denda kepada pembeli jika pembeli lalai dalam membayar kewajibannya sesuai dengan akad, dan denda akan diakui sebagai bagian dana kebajikan (sesuai dengan PSAK 102 paragraf 29)

e. PT. Bank Muamalat Indonesia, Tbk akan menyajikan piutang murabahah sebesar nilai bersih yang dapat direalisasikan, yaitu saldo piutang murabahah dikurangi penyisihan kerugian piutang. (sesuai dengan PSAK 102 paragraf 37) 
f. PT. Bank Muamalat Indonesia, Tbk menyajikan margin murabahah tangguhan sebagai pengurang (contra account) piutang murabahah. (sesuai dengan PSAK 102 paragraf 38)

g. PT. Bank Muamalat Indonesia, Tbk dapat menguasakan kepada nasabah untuk melakukan pembelian barang atas nama dan untuk Bank dengan spesifikasi yang telah disepakati antara bank dan nasabah. Selanjutnya penyerahan barang akan langsung dari supplier kepada nasabah.

\section{KESIMPULAN DAN SARAN}

Setelah melakukan analisis dari hasil penelitian yang telah dibahas di bab sebelumnya, maka penulis akan memberikan beberapa kesimpulan dan saran dari uraian-uraian yang terdapat pada bab terdahulu.

\section{Kesimpulan}

1. PT. Bank Muamalat Indonesia, Tbk adalah sebuah bank yang tata cara beroperasinya (baik penyaluran dana dan penghimpunan dana) mengikuti Al quran dan Hadis .

2. PT. Bank Muamalat Indonesia, Tbk telah menerapkan sistem pembiayaan murabahah yang operasionalnya telah sesuai dengan PSAK 102 tentang akuntansi murabahah. Di dalam pelaksanaan pembiayaan murabahah, PT. Bank Muamalat Indonesia, Tbk bertindak sebagai penjual dan nasabah sebagai pembeli.

3. Harga jual dalam pembiayaan murabahah adalah harga perolehan yang ditambah dengan keuntungan yang disepakati antara bank selaku penjual dan nasabah selaku pembeli. Bank harus mengungkapkan biaya perolehan barang tersebut kepada nasabah.

4. Segala aktivitas PT. Bank Muamalat Indonesia, Tbk mengacu kepada PSAK dan Fatwa Dewan Syariah Nasional.

\section{Saran}

1. PT. Bank Muamalat Indonesia, Tbk harus terus melakukan inovasi di tengah maraknya perkembangan perbankan syariah saat ini. Khususnya melalui peningkatan kualitas pelayanan, pemasaran, dan Sumber Daya Insani (SDI) yang memegang amanah yang sangat berat, sehingga menjadi insan yang kompeten di bidang perbankan syariah.

2. Pengembangan Usaha Mikro Kecil Menengah (UMKM) hendaknya menjadi perhatian dari PT. Bank Muamalat Indonesia, Tbk dalam penyaluran dana melalu pembiayaan murabahah. Sehingga perkembangan ekonomi mikro yang sering terkendala masalah kurangnya modal untuk pengembangan usaha dapat berjalan dengan pesat karena didukung oleh pembiayaan yang diberikan oleh Bank Syariah yang bebas dari bunga, dan secara langsung dapat merealisasikan kesejahteraan umat.

3. Untuk menarik minat dan kesadaran masyarakat, hendaknya PT. Bank Muamalat Indonesia, Tbk. lebih mensosialisasikan keberadaanya di tengah-tengah masyarakat luas, dengan memperkenalkan produk-produk perbankan syariah termasuk pembiayaan murabahah. Selain itu dengan memperluas jaringan kerja hingga ke daerah-daerah. Hal ini dikarenakan, 
program yang telah ada sekarang yang bekerjasama dengan PT. Pos Indonesia belum disertai dengan sosialisasi yang memadai ke masyarakat.

\section{DAFTAR PUSTAKA}

Al-qur'an dan Hadist

Anshori, H, Adul Ghafur, 2008. Tanya Jawab Perbankan Syariah, UII Press, Yogyakarta, hal 53.

Antonio, M. Syafi'i, 1999. Bank Syariah dari Teori ke Praktek, Gema Insani, Jakarta

Anwar, Syamsul, 2007. Hukum Perjanjian Syariah, PT. RajaGrafindo Persada, Jakarta, hal 15

Arifin, Zainul, 1999. Memahami Bank syariah Lingkup, Peluang, Tantangan dan Prospek, Alvabet, Jakarta, hal 63.

Ascarya, 2007. Akad dan Produk Bank Syariah, PT. RajaGrafindo Persada, Jakarta, hal 81.

Harahap, Sofyan safri, dkk, 2004. Akuntansi Perbankan Syariah, edisi 1, LPFE USAKTI, Jakarta, hal 15 dan 100

Ikatan Akuntan Indonesia, 2009. Standar Akuntansi Keuangan, Salemba Empat, Jakarta

Jurusan akuntansi, Fakultas Ekonomi Universitas Sumatera Utara, 2004. Buku Petunjuk Teknis Penulisan Proposal Penelitian dan Penulisan Skripsi, Medan.

Karim, Adiwarman, 2006. Bank Islam Analisis Fiqih dan Keuangan, Cetakan 3, PT. RajaGrafindo Persada, Jakarta, hal 113 dan 231

Nurhayati, Sri dan Wasilah, 2008. Akuntansi Syariah di Indonesia, edisi 1, Salemba 4, Jakarta, hal 160.

Saeed, Abdullah, 2004. Menyoal Bank Syariah Kritik atas Intrepretasi Bunga Bank Kaum Neo-Revivalis, Paramadina, Jakarta, hal 118.

Santoso, Bambang, 2004. Analisis Sistem Pembiayaan Murabahah pada BNI Syariah Cabang Medan, Medan 
Siregar, Liesma Maywarni, 2005. Analisis Penerapan Transaksi Murabahah pada PT. BPRS Syariah Al-Washliyah Medan, Medan

Sumitro, Warkum, 2004. Asas-asas Perbankan Islam dan Lembaga-lembaga terkait (BAMUI, Takaful dan Pasar Modal Syariah) di Indonesia, Cetakan 4, PT. RajaGrafindo Persada, Jakarta, hal 22.

Triyuwono, Iwan, 2009. Perspektif, Metodologi, dan Teori Akuntansi Syariah, Edisi 1, Rajawali Pers, Jakarta, hal 179

Undang-Undang Republik Indonesia No. 21 tahun 2008 tentang Perbankan Syariah

Wirdyaningsih, 2007. Bank dan Asuransi Islam di Indonesia, edisi 1, cetakan 3, Kencana, Jakarta, hal 5

Yaya, rizal, dkk, 2009. Akuntansi Perbankan Syariah Teori dan Praktek Kontemporer, Salemba 4, Jakarta, hal 179. 